\title{
Nonarteritic anterior ischemic optic neuropathy after uneventful phacoemulsification: case report
}

\author{
Neuropatia óptica isquêmica anterior nãoarterítica após facoemulsificação:relatodecaso
}

\author{
Bruno Machado Fontes ${ }^{1}$ \\ Liang Shih Jung'2 \\ Eduardo Sone Soriano ${ }^{3}$ \\ Carlos Filipe Chicani ${ }^{4}$
}

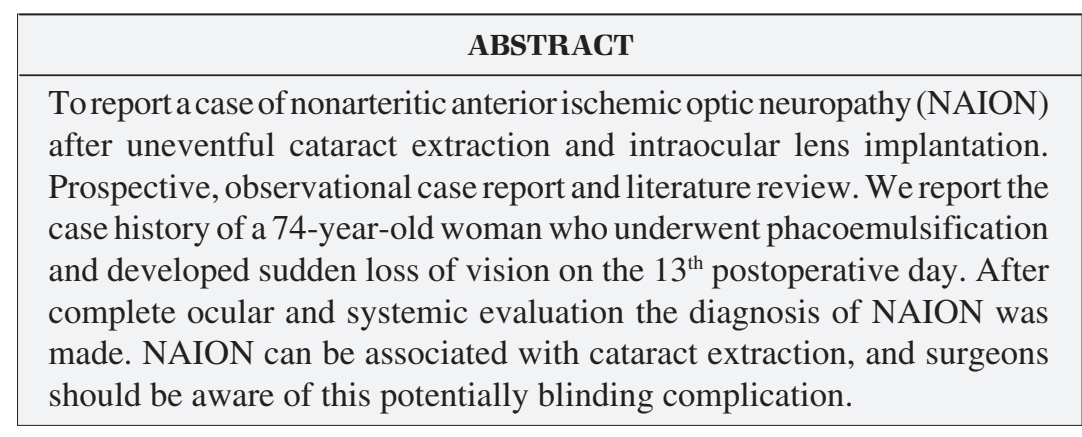

Keywords: Optic neuropathy, ischemic; Cataract extraction/methods; Phacoemulsification Optic nerve diseases; Case reports [Publication type]
Trabalho realizado no Departamento de Oftalmologia da Universidade Federal de São Paulo - UNIFESP - São Paulo (SP) - Brasil.

${ }^{1}$ Pós-Graduando do Departamento de Oftalmologia da Universidade Federal de São Paulo - UNIFESP - São Paulo (SP) - Brasil.

${ }^{2}$ Médico Oftalmologista do Departamento de Oftalmologia da UNIFESP - São Paulo (SP) - Brasil.

${ }^{3}$ Médico Oftalmologista do Departamento de Oftalmologia da UNIFESP - São Paulo (SP) - Brasil.

${ }^{4}$ Médico Oftalmologista do Departamento de Oftalmologia da UNIFESP - São Paulo (SP) - Brasil.

Corresponding author: Rua Augusto Camossa Saldanha, 55 - Rio de Janeiro (RJ) CEP 22793-310

E-mail: brunofontes@oftalmo.epm.br brunomfontes@terra.com.br

Recebido para publicação em 04.01.2006

Última versão recebida em 12.09.2006 Aprovação em 24.11.2006

Nota Editorial: Depois de concluída a análise do artigo sob sigilo editorial e com a anuência do Dr. Breno Barth sobre a divulgação de seu nome como revisor, agradecemos sua participação neste processo.

\section{INTRODUCTION}

Nonarteritic anterior ischemic optic neuropathy (NAION) is a devastating form of visual impairment that results from inadequate blood supply to the posterior ciliary arteries ${ }^{(1-5)}$. It is characterized by sudden, painless, mostly irreversible, and generally nonprogressive visual loss accompanied by nerve fiber bundle field defects, a relative afferent pupillary defect and optic disk edema ${ }^{(3-4,6-13)}$.

Arterial hypertension, diabetes mellitus, hypercholesterolemia, ischemic heart disease, cerebrovascular disease, migraine, sleep apnea syndrome and anterior segment surgeries have been identified as risk factors for NAION ${ }^{(3-5,}$ ${ }^{8,10-16)}$. No treatment is available since neither steroids nor surgical optic nerve sheath fenestration has proved to be effective ${ }^{(5,10-11)}$. Approximately one occurrence of NAION is expected in every 2000 cataract extractions, and a history of this disease in the fellow eye may be an additional risk factor ${ }^{(16)}$.

Two distinct categories of cataract extraction-associated NAION have been reported ${ }^{(15-16)}$ : immediate type, which occurs within hours to days after surgery, and delayed type, which occurs weeks to months after surgery after a period of good vision. We report a case of delayed NAION with an associated cilioretinal artery occlusion after uneventful phacoemulsification.

\section{CASE REPORT}

A 74-year-old white woman underwent an uneventful phacoemulsification and intraocular lens implantation, under peribulbar anesthesia, for a 3+ nuclear cataract on her left eye. She had systemic arterial hypertension, controlled with captopril (50 mg/day), and no other systemic or ocular disease, unless a finding of bilateral small optic disks with a cup-to-disk ratio of 0.1 in both eyes on preoperative examination. 
On the first postoperative day she presented with a BCVA of 20/40 in the operated eye, with a slight corneal edema and an intraocular pressure of $18 \mathrm{mmHg}$. A topical medication (Tobradex ${ }^{\circledast}$ - Alcon, Fort Worth, TX, USA) every 3 hours and return to a programmed visit after one week was prescribed. On the first-week visit she presented without ocular complaints, an uncorrected visual acuity of 20/20 and an intraocular pressure of $16 \mathrm{mmHg}$ in operated eye.

On the $13^{\text {th }}$ postoperative day she observed a sudden and painless vision loss on wakening. At the first examination, six hours from the beginning of symptoms, she had a BCVA of hand motion, with afferent pupillary defect, no alterations on anterior segment examination (Figure 1) and an intraocular pressure of $16 \mathrm{mmHg}$ in the left eye. On fundus examination we noticed a pallid optic disk and swelling, associated with cilioretinal artery occlusion (Figure 2). An optical coherence tomography was obtained, confirming these findings (Figure 3).

She underwent a complete laboratorial and clinical evaluation, and the hypothesis of arteritic ischemic optic neuropathy was excluded. Three days after the beginning of symptoms visual acuity was no light perception, with an important afferent papillary defect in the affected eye.

\section{DISCUSSION}

Using a three-dimensional digital reconstruction of an optic nerve infarct from a patient with NAION, Tesser et al ${ }^{(6)}$ showed that it represents a form of compartment syndrome that causes tissue ischemia. As the infarct is located in the confines of the sclera, its rigidity confines the swollen optic nerve, causing the compartment syndrome.

A recurrent event in the contralateral eye is expected to occur in 24 to $48 \%$ of patients within a period of five to eleven

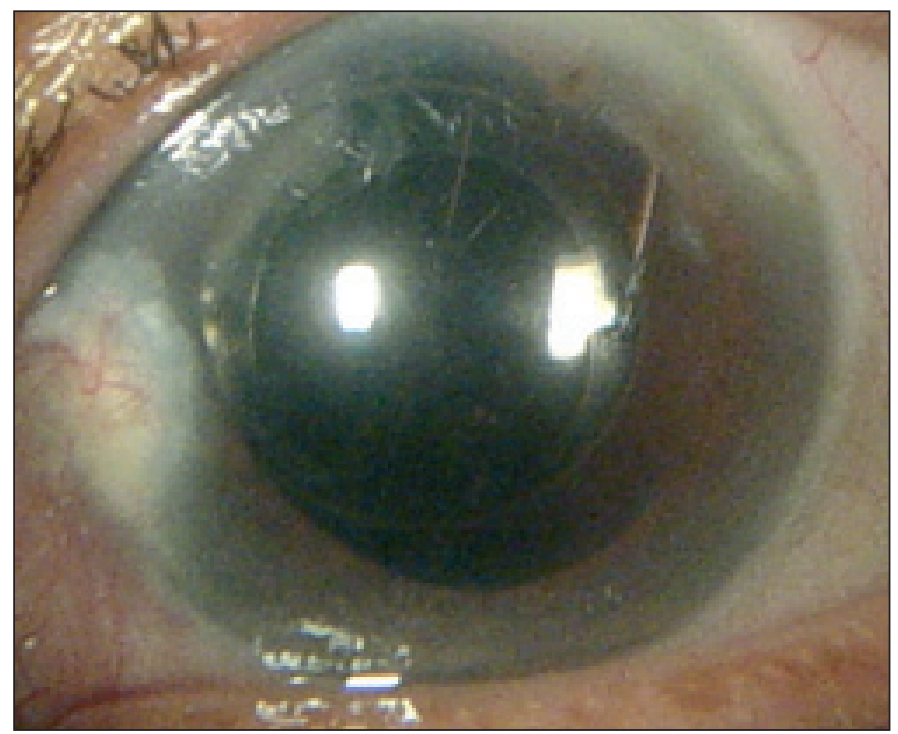

Figure 1 - Slit lamp photograph showing a quiet anterior segment (note dilated pupil with no mydriatic administration)

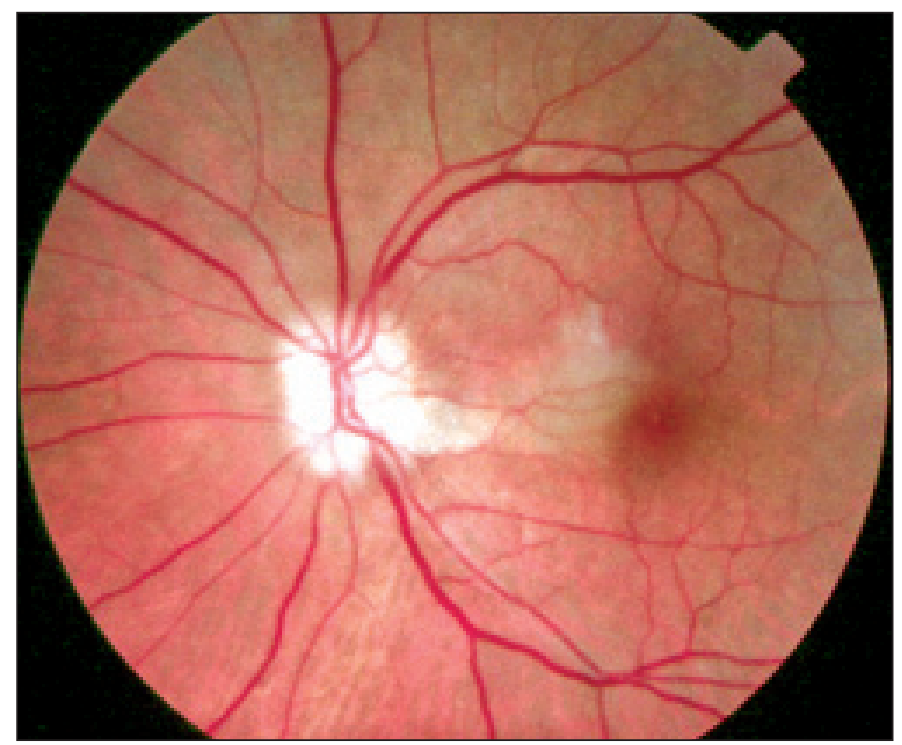

Figure 2 - Fundus photograph: optic disk pallor and swelling, associated with cilioretinal artery occlusion
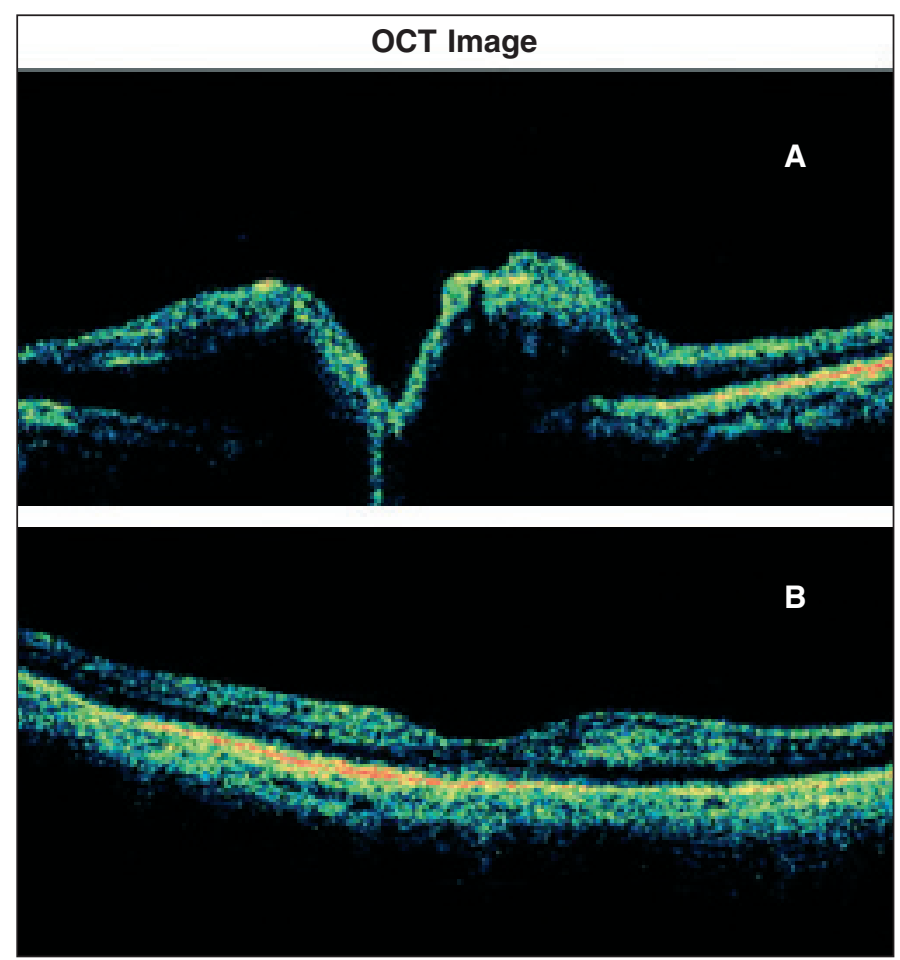

Figure 3 - OCT image: optic nerve swelling (A) and normal foveal depression appearance (B)

years ${ }^{(3)}$. Aspirin administration (100-325 mg/day) has shown to be effective in reducing the short-term frequency of second eye involvement ${ }^{(3,17)}$.

According to the findings by Hayreh et $\mathrm{al}^{(18)}$ in a large series of NAION, $73.3 \%$ of patients discovered visual loss upon first awakening or at first opportunity to use vision critically after sleeping. Lana ${ }^{(13)}$ also found a predominance of NAION onset at night. 
In other study, Hayreh et $\mathrm{al}^{(19)}$ showed that nocturnal hypotension may reduce the optic nerve head blood flow below a critical level, and thereby may play a role in the pathogenesis of NAION. Mojon et $\mathrm{al}^{(11)}$ found a high prevalence of sleep apnea syndrome in patients with NAION. Sleep apnea syndrome is recognized as an important risk factor for cardiovascular and neurovascular diseases ${ }^{(11)}$.

Unfortunately, our patient could not be evaluated by optic nerve head blood supply measurements or overnight polysomnography. But it seems likely that the event occurred during the night, as symptoms started during the very early morning hours.

Our report does not allow any conclusions about a direct causal relationship between phacoemulsification and NAION, but we may hypothesize an association between these two entities. McCulley et $\mathrm{al}^{(15-16)}$ showed that cataract extraction and intraocular lens implantation are associated with an increased incidence of NAION, and it occurs with an average onset of approximately 35 days, ranging widely from hours to nearly five months postoperatively.

Although the risk of NAION is very low after cataract surgery, surgeons should be aware of this complication. Patients at risk of NAION are those with crowded optic nerves with a cupto-disk ratio of less than 0.1 ("disk-at-risk") (5,20), and maybe aspirin should be prescribed as a prophylaxis, particularly in those who experienced NAION on the fellow eye.

\section{RESUMO}

Os autores relatam um caso de neuropatia óptica isquêmica anterior (NOIA) não-arterítica após facoemulsificação de rotina e implante de lente intra-ocular. Uma paciente de 74 anos do sexo feminino foi submetida à cirurgia de catarata pela técnica de facoemulsificação e desenvolveu perda súbita e grave de visão no décimo terceiro dia pós-operatório. Após extensa investigação clínica e laboratorial, ocular e sistêmica, foi feito o diagnóstico de NOIA não-arterítica. Feita revisão da literatura, encontrando-se descrição desta complicação em raros casos associada a facectomia e implante de lente intra-ocular.

Descritores: Neuropatia óptica isquemica; Extração de catarata/métodos; Facoemulsificação; Doenças do nervo óptico; Relato de casos [Tipo de publicação]

\section{REFERENCES}

1. Hayreh SS. Posterior ciliary artery circulation in health and disease: the Weisenfeld lecture. Invest Ophthalmol Vis Sci. 2004;45(3):749-57;748.

2. Leiba H, Rachmiel R, Harris A, Kagemann L, Pollack A, Zalish M. Optic nerve head blood flow measurements in non-arteritic anterior ischaemic optic neuropathy. Eye. 2000;14(Pt 6):828-33.

3. Salomon O, Huna-Baron R, Steinberg DM, Kurtz S, Seligsohn U. Role of aspirin in reducing the frequency of second eye involvement in patients with non-arteritic anterior ischaemic optic neuropathy. Eye. 1999;13(Pt 3a):357-9.

4. Peixoto MAL. A etiologia da neuropatia óptica isquêmica anterior; estudo de 328 casos e revisäo de literatura. Rev Bras Oftalmol. 1994;53(6):53-62.

5. Optic nerve decompression surgery for nonarteritic anterior ischemic optic neuropathy (NAION) is not effective and may be harmful. The Ischemic Optic Neuropathy Decompression Trial Research Group. JAMA. 1995;273(8):625-32.

6. Tesser RA, Niendorf ER, Levin LA. The morphology of an infarct in nonarteritic anterior ischemic optic neuropathy. Ophthalmology. 2003;110(10):2031-5.

7. Foroozan R, Buono LM, Savino PJ. Optic disc structure and shock-induced anterior ischemic optic neuropathy. Ophthalmology. 2003;110(2):327-31.

8. Prenner JL, Sharma A, Ibarra MS, Maguire AM, Volpe NJ. Prolonged premonitory optic disc signs in anterior ischemic optic neuropathy. J Neuroophthalmol. 2002;22(2):110-2.

9. Oto S, Yilmaz G, Cakmakci S, Aydin P. Indocyanine green and fluorescein angiography in nonarteritic anterior ischemic optic neuropathy. Retina. 2002; 22(2):187-91.

10. Newman NJ, Scherer R, Langenberg P, Kelman S, Feldon S, Kaufman D, Dickersin K. Ischemic Optic Neuropathy Decompression Trial Research Group. The fellow eye in NAION: report from the ischemic optic neuropathy decompression trial follow-up study. Am J Ophthalmol. 2002;134(3):317-28.

11. Mojon DS, Hedges TR $3^{\text {rd }}$, Ehrenberg B, Karam EZ, Goldblum D, AbouChebl A, et al. Association between sleep apnea syndrome and nonarteritic anterior ischemic optic neuropathy. Arch Ophthalmol. 2002;120(5):601-5.

12. Moro F, Vieira Netto M, Soubhia FS, Oliveira JPA, Ambrósio Júnior R. Neuropatia óptica isquêmica näo arterítica pós-facoemulsificaçäo. Rev Bras Oftalmol. 2001;60(8):591-4.

13. Lana MA. Horário de instalação da neuropatia óptica isquêmica anterior. Diferenciação entre as formas arterítica e näo arterítica. Arq Bras Oftalmol 1994;57(4):254-8

14. Hayreh SS, Joos KM, Podhajsky PA, Long CR. Systemic diseases associated with nonarteritic anterior ischemic optic neuropathy. Am J Ophthalmol. 1994;118(6):766-80.

15. McCulley TJ, Lam BL, Feuer WJ. Nonarteritic anterior ischemic optic neuropathy and surgery of the anterior segment: temporal relationship analysis. Am J Ophthalmol. 2003;136(6):1171-2.

16. McCulley TJ, Lam BL, Feuer WJ. Incidence of nonarteritic anterior ischemic optic neuropathy associated with cataract extraction. Ophthalmology. 2001; 108(7):1275-8.

17. Beck RW, Hayreh SS, Podhajsky PA, Tan ES, Moke PS. Aspirin therapy in nonarteritic anterior ischemic optic neuropathy. Am J Ophthalmol. 1997;123 (2):212-7.

18. Hayreh SS, Podhajsky PA, Zimmerman B. Nonarteritic anterior ischemic optic neuropathy: time of onset of visual loss. Am J Ophthalmol. 1997;124(5):641-7.

19. Hayreh SS, Zimmerman MB, Podhajsky P, Alward WL. Nocturnal arterial hypotension and its role in optic nerve head and ocular ischemic disorders. Am J Ophthalmol. 1994;117(5):603-24.

20. Danesh-Meyer HV, Savino PJ, Sergott RC. The prevalence of cupping in endstage arteritic and nonarteritic anterior ischemic optic neuropathy. Ophthalmology. 2001;108(3):593-8.

Nos artigos enviados para publicação, o nome dos autores e suas afiliações devem estar completos. Isso facilitará a indexação e os links com as bases de dados e o CV Lates. 